\title{
The Rhenohercynian passive margin of SW England: development, inversion and extensional reactivation.
}

\author{
Robin K. Shail ${ }^{\mathrm{a}, *}$ and Brian E. Leveridge ${ }^{\mathrm{b}}$ \\ ${ }^{a}$ Camborne School of Mines, School of Geography, Archaeology and Earth Resources, \\ University of Exeter, Cornwall Campus, Penryn, TR10 9EZ United Kingdom \\ ${ }^{b}$ British Geological Survey (HRA), Keyworth, Nottingham NG12 5 GG United Kingdom \\ * Corresponding author email: R.K.Shail@ex.ac.uk
}

\begin{abstract}
The SW England Rhenohercynian passive margin initiated with rift-related non-marine sedimentation and bimodal magmatism (late Lockhovian). Continued lithospheric extension resulted in the exhumation of mantle peridotites and limited seafloor spreading (EmsianEifelian). Variscan convergence commenced during the late Eifelian and was coeval with rifting further north. Collision was marked by the early Carboniferous emergence of deep marine sedimentary/volcanic rocks from the distal continental margin, oceanic lithosphere, pre-rift basement and upper plate gneisses (correlated with Mid-German Crystalline High of Saxothuringian Zone). Progressive inversion of the passive margin was strongly influenced by rift basin geometry. Convergence ceased in the late Carboniferous and was replaced by an extensional regime that reactivated basin controlling/thrust faults and reorientated earlier fabrics (Start-Perranporth Zone). The resultant exhumation of the lower plate was accompanied by emplacement of the Early Permian SW England granites and was contemporaneous with upper plate sedimentary basin formation above the reactivated Rhenohercynian suture. The Rhenohercynian passive margin probably developed in a marginal basin north of the Rheic Ocean or, possibly, a successor basin following its closure. The Lizard ophiolite is unlikely to represent Rheic Ocean floor or associated forearc (SSZ) crust. The Rheic and Rhenohercynian sutures may be coincident, or the Rheic suture may be located further south in the Léon Domain.
\end{abstract}

\section{Résumé}

Help from editors required here please. 
Keywords: Variscan, Rhenohercynian, passive margin, ophiolite, inversion, Rheic

\section{Introduction}

The Upper Palaeozoic massif of SW England has long been recognized as an integral part of the European Variscides and correlation with the Rhenohercynian Zone / South Portuguese Zone of mainland Europe is widely accepted, e.g. [38,45,62]. SW England features prominently in Variscan tectonic models due to the presence of the Lizard ophiolite $[11,52]$.

A 40 year programme of 1:10,000 scale geological re-mapping and collaborative research by the British Geological Survey (BGS) in SW England forms the basis for much of this paper (Fig. 1). It has substantially refined understanding and models of passive margin evolution, Variscan convergence and post-Variscan sedimentation, e.g. [18,19,29,35,37,5860,69]. In addition, extensional reactivation of the Rhenohercynian suture zone and inverted passive margin has been interpreted to exert a significant control on Early Permian magmatism and sedimentary basin development [46,88-90].

The purpose of this contribution is to combine the above elements into an integrated overview of the Upper Palaeozoic tectonic evolution of SW England that demonstrates: (i) Early Devonian to Early Carboniferous development of the Rhenohercynian passive margin (northern lower plate), (ii) Mid-Late Devonian accretion along the southern active margin (upper plate represented by Normannian Nappe, correlated with the Mid-German Crystalline High of the Saxothuringian Zone), (iii) Carboniferous collision and progressive inversion of the passive margin, and (iv) latest Carboniferous to Early Permian post-convergence extension, magmatism, mineralization and sedimentary basin development. The wider implications of the SW England data for models of Variscan tectonics and the Rheic Ocean are then discussed.

\section{Development of the passive margin}

Rift and extensional basin models have been progressively refined since the 1970s, as more stratigraphical and structural detail has emerged from the BGS mapping programme $[63,83,87]$. The full definition of basins has recently been completed $[58,60]$. Evidence for the development of the passive margin is preserved within the Lizard Complex and DevonianCarboniferous basins to the north (Fig. 1). 


\subsection{Pre-rift basement}

Pre-rift basement is exposed within the Lizard Complex (Fig. 2), where it occurs structurally below mantle peridotites, e.g. [49,72]. The Man of War Gneiss comprises tonalitic gneiss with continental magmatic arc affinities and a late Cambrian magmatic U-Pb zircon age of 499 $+8 /-3(2 \sigma) \mathrm{Ma}$ [81]. It has a faulted upper boundary with amphibolite facies metasedimentary and metabasic rocks of the Old Lizard Head Formation [49], that host granodiorite sheets with similar magmatic ages and geochemistry as the Man of War Gneiss [17,69]. Further north, rare xenoliths of foliated granitoid occur in the parautochthonous Late Devonian syn-rift basalts of the Gramscatho Basin [39,40].

\subsection{Lizard Complex}

Outcrop, borehole and geophysical data indicate that the Lizard Complex (Fig. 2) comprises c.1-1.5 km of fault-bounded sheets underlain by Devonian metasedimentary rocks $[6,11,27,49,76]$. The mantle peridotites are predominantly spinel lherzolites that initially equilibrated at $1119^{\circ} \mathrm{C}$ and $15.7 \mathrm{kbar}$ and then partially re-equilibrated to plagioclase peridotite $\left(1070{ }^{\circ} \mathrm{C}, 11 \mathrm{kbar}\right)$ [18]. There are transitional contacts with kilometre-scale higher strain zones, comprising mylonitic plagioclase peridotites (equilibrated at $1010^{\circ} \mathrm{C}, 7.5 \mathrm{kbar}$ ) and mylonitic amphibole peridotites (equilibrated at $990^{\circ} \mathrm{C}, 7.5 \mathrm{kbar}$ ), that commonly exhibit a NNW-SSE striking steeply dipping foliation and down-dip mineral lineation [18].

In the east, the spinel lherzolites are overlain by the $c .1 \mathrm{~km}$ thick Crousa Gabbro [37]. It is cut by three sets of NW-SE striking dolerite dykes, each with a slightly different MORB geochemistry $[53,75]$. The two earlier sets were rotated by NW-SE striking brittle-ductile shear zones, that thinned the crust by c. $40 \%$, before emplacement of the final subvertical set that forms the lowermost part of a sheeted dyke complex [75]. These shear zones have locally controlled syntectonic emplacement of Fe-Ti oxide gabbros [48]. Variably deformed gabbro and dolerite sheets are also hosted by peridotite [3,41].

The mafic and ultramafic rocks of the Traboe Cumulate Complex [55] are interlayered with the mylonitic peridotites and record the same fabric [18,19]. Cambro-Ordovician zircon cores imply proximity to pre-rift basement [69]. Quartz-feldspar-amphibole veins developed during granulite facies partial melting have yielded a magmatic U-Pb zircon age of $397 \pm 2$ $(2 \sigma) \mathrm{Ma}$ (late Emsian) [16]. In the south and west, the mantle peridotites are underlain by the Landewednack Amphibolites; their protoliths are inferred to be basalts, dolerite dykes and minor gabbros that have a similar MORB geochemistry to the Crousa Gabbro [19,37]. SHRIMP U-Pb ages of c. $500 \mathrm{Ma}$ from zircons in rare metasedimentary rocks are similar to those in pre-rift basement $[17,69]$. An early high temperature $\left(550-700{ }^{\circ} \mathrm{C}, 2-6 \mathrm{kbar}\right)$ prograde 
brown amphibole fabric, dated at 393-386 Ma by SHRIMP U-Pb metamorphic zircon also exhibits kinematic similarity with the mylonitic peridotites $[19,69]$.

\subsection{Devonian-Early Carboniferous rift basins}

North of the Lizard Complex, Devonian-Carboniferous successions are preserved within six, E-W trending, sedimentary basins (Fig. 1). The oldest succession occurs in the Looe Basin (Fig. 3a) and comprises Lochkovian-Pragian non-marine (Dartmouth Group) and Pragian shallow marine (Meadfoot Group) sedimentary rocks and bimodal rift-related igneous rocks $[60,65]$. Significant northerly-derived sediment input occurred in the late Emsian (Staddon Formation) and may have been coeval with a hiatus in subsidence; it resulted in the brief resumption of non-marine depositional environments. The development of later basins is indicated by the availability or blocking of sediment supply, including from inter-basinal highs. The progressive northwards initiation of one or more half graben or graben with distinct stratigraphies is recorded (Fig. 3): South Devon Basin (late Emsian), Tavy Basin (Givetian) and Culm Basin (late Famennian) [58,60]. A segmented marine shelf with limestone reefs on basement highs persisted throughout much of the Middle-Upper Devonian (Fig. 3b,c). To the south, the syn-rift infill of the Gramscatho Basin (Fig. 4) is largely occluded by subsequent Upper Devonian syn-convergence sedimentation. Seismic refraction studies imply pre-rift continental basement may occur within the Carrick Nappe [27]. A late syn- to post-rift succession is preserved at the base of the Veryan Nappe (Fig. 4), where Eifelian mudstones, radiolarian cherts, platform-derived limestone turbidites and basementsourced sandstones overlie T-MORB pillow basalts [58,59]. The Start Complex (Fig. 1) comprises greenschist facies metasedimentary and metavolcanic rocks with N-MORB characteristics [36] that might be correlated with allochthonous parts of Gramscatho Basin.

\section{Convergence and passive margin inversion}

Seismic reflection investigations to the south of the peninsula have identified prominent, semi-continuous, SE dipping seismic reflectors within the crust that are generally interpreted as (reactivated) Variscan thrusts, some of which have an onshore expression $[8,43,57]$. The geometry and extent of these reflectors is consistent with the southern part of SW England forming a Variscan orogenic wedge [57].

\subsection{Onset of convergence and accretion of the distal passive margin}

The Gramscatho Basin succession is dominated by a southerly-sourced deep marine siliciclastic depositional system that prograded across the distal passive margin during its 
progressive frontal accretion to the upper plate in the Mid- to Upper Devonian; it is preserved in a parautochthonous northern region plus the Carrick, Veryan and Dodman nappes (Fig. 4) [44,57-59]. The onset of convergence is marked in the Veryan Nappe by the transition, from a late Eifelian syn- to post-rift hemipelagic-dominated succession (Pendower Formation), to a deep marine sandstone-dominated succession (Carne Formation) and overlying olistostrome (Roseland Breccia Formation), up to $2 \mathrm{~km}$ thick, in the footwall of the Dodman and Lizard nappes [7,44].

The olistostrome clast assemblage includes sandstones, mudstones, limestone (Silurian, Lower Devonian and Eifelian), radiolarian chert (Eifelian), basalt, gabbro, and rare serpentinite, quartzites (Ordovician), slates, phyllites, schists, granites (variably foliated), rhyolites and amphibolites $[5,35,58]$. The Ordovician quartzites have a Llandeilo trilobite and brachiopod fauna that has been correlated with Armorican successions [78]. The upper, most proximal, parts of the olistostrome contain kilometre scale megaclasts of T-MORB pillow lavas and dolerite sheets [33,34]. There is also contemporaneous bimodal magmatism [58].

The final stages of accretion are marked by Famennian-?Tournaisian olistostromes at the top of the parautochthonous succession that record uplift and erosion of the Carrick Nappe $[44,58]$. They were immediately preceded, in the parautochthon, by the late FrasnianFamennian eruption of substantial volumes of basalt lavas and emplacement of dolerite/gabbro sills, all with enriched T-MORB geochemistry [34,36,59].

Accretion of the Gramscatho Group succession resulted in deformation and intermediate pressure facies series anchizonal-epizonal regional metamorphism [96]. D1 deformation is characterized by ENE-WSW slaty cleavage, tight to isoclinal curvilinear folds, and a NNW-SSE mineral lineation that are compatible with a top sense of shear to the NNW [57]. Metamorphic inclusion fluid studies in the Carrick Nappe indicate peak (syn-D1) P/T conditions of $\sim 300-330^{\circ} \mathrm{C}$ and 2.9-3.5 kbar [88]. K-Ar whole rock data [26], recalculated with revised decay constants, and excluding contact metamorphic overprinted samples, yield early Tournaisian to Famennnian mean ages of $358 \pm 8(2 \sigma)$ (Carrick Nappe), $361 \pm 8(2 \sigma)$ (Veryan Nappe) and $371 \pm 8(2 \sigma)$ Dodman Nappe. A more recent precise Ar-Ar, whole rock age plateau for the Dodman Nappe is $385 \pm 2$ Ma (earliest Frasnian) [15].

In the Lizard Complex, the boundary between mantle peridotites and the underlying Landewednack Amphibolites is formed by gently dipping amphibolite facies shear zones that have a top sense of shear to the NW [19]. Deformed, variably commingled and mixed, mafic and felsic igneous rocks (Kennack Gneiss) intrude the boundary zone [11,82]. The mafic component has an E-MORB geochemistry and the felsic component has a continental crust source $[69,82]$. Estimates of magmatic age by $\mathrm{U}-\mathrm{Pb}$ zircon methods vary from $376.4 \pm 1.7$ 
(2б) Ma (late Frasnian, by TIMS) [82] to $396 \pm 20$ Ma (early Eifelian, by SHRIMP) [69]; see discussion [17]. Amphibolite facies emplacement-related deformation and metamorphism of the Landewednack Amphibolite, Kennack Gneiss, Man of War Gneiss and Old Lizard Head Formation is all dated between latest Frasnian and earliest Tournaisian [15,80-82].

The upper plate (Normannian Nappe), defined by offshore seismic mapping [44,45,57], crops out as garnetiferous granite gneiss at Eddystone Rocks (Fig. 1); it has a Frasnian K-Ar biotite cooling age, recalculated using revised decay constants, of $382 \pm 17 \mathrm{Ma}$ [66].

\subsection{Collision and basin inversion}

The orogenic wedge, comprising frontally accreted elements of the distal passive margin (Gramscatho Basin / Lizard Complex) and upper plate (Normannian Nappe) collided with the continental slope in the earliest Carboniferous. South of the Culm Basin, K-Ar whole rock ages, reflecting syn-D1 anchizone-epizone grade regional metamorphism, range from 345$325 \mathrm{Ma}$ (late Tournaisian-early Namurian) $[26,96]$ and are consistent with ${ }^{40} \mathrm{Ar}-{ }^{39} \mathrm{Ar}$ wholerock laser probe dates for Looe Basin anchizonal metamorphism of 331-329 $\pm 2 \mathrm{Ma}$ [15]. Shortening was accommodated by 'thick-skinned' inversion of basin fill and pre-rift basement $[58,83,87]$ above a regional décollement at the base of the middle crust [12]. Rift basin geometry exerted a dominant control on the style of deformation (Fig. 5c). S-dipping half graben bounding faults were reactivated as thrusts and often developed km scale hangingwall antiforms; successions from highs were locally thrust northwards, via footwall shortcuts, over adjacent basinal sequences [60]. Backthrusting, controlled by $\mathrm{N}$-dipping faults defining the southern margin of full graben, e.g. Tavy Basin, Culm Basin, resulted in syn-D1 facing confrontations with regional persistence (Fig. 5d) [58,60]. Mesoscopic D1 structures include thrusts, a ubiquitous cleavage, and close to isoclinal folds, that all typically trend E-W; extension lineations are generally orientated NNW-SSE. Dextral displacement on NW-SE strike-slip faults developed late in D1 [60].

Syn-rift sedimentation and basaltic magmatism persisted along the southern margin of the Culm Basin until the late Visean. These successions were expelled southwards during early-mid Namurian D1 inversion and include Tournaisian turbidite sandstones (St Mellion Formation) that have southerly derived palaeocurrents and include clasts of low-grade metamorphic rocks and K-feldspar that were probably derived from the GramscathoNormannian orogenic wedge (Fig. 5a) [58]. However, the main part of the Culm Basin fill, as currently observed, comprises Namurian and Westphalian sandstones and mudstones (Crackington, Bude and Bideford formations) that were sourced from the north and east and deposited synchronously with inversion [58]. 
A second episode of deformation (D2) is variably developed throughout SW England; for post-Namurian successions of the Culm Basin and the North Devon Basin, it was the first episode of post-lithification deformation. D2 deformation is strongly partitioned, typically into zones of reactivated or out-of-sequence thrusts, and is characterized by NE or ENE trending folds and a gently to steeply inclined crenulation cleavage [60]. The kinematics of D2 are compatible with a top sense of shear to the NNW or NW; D2 structures are commonly co-axial with D1 structures, but there can be an anticlockwise divergence of up to $30^{\circ}$ [58]. Transpressive fabrics are developed where there is obliquity with earlier basinal and deformation structures. K-Ar whole rock ages for the North Devon Basin group around 305 Ma $[26,96]$.

\section{Extensional reactivation}

The youngest deformed rocks of the Culm Basin are Westphalian C in age; Variscan convergence across SW England ended in the late Carboniferous c. 305-300 Ma [29]. It was replaced by a latest Carboniferous-Early Permian NNW-SSE extensional regime that brought about substantial thinning of the crust, largely through reactivation of earlier structures, and was associated with sedimentary basin development and voluminous magmatism $[46,88]$.

\subsection{Structures developed during extension}

In the orogenic wedge (Gramscatho Group/Lizard Complex), postconvergence deformation (D3) is represented by zones of distributed shear, detachments and later high-angle faults $[1,2,89]$. Zones of distributed shear are ubiquitous throughout the parautochthonous footwall of the Carrick Thrust and are defined by ENE striking domains of F3 folds and a subhorizontal or NNW dipping cleavage (S3) that locally transposes earlier fabrics. Fold vergence is predominantly to the SSE, although can undergo reversal in high-strain zones $[1,2]$. Detachments occur in proximity to the Carrick and Dodman thrusts and are ENE striking, low-angle faults, generally bedding and cleavage parallel, that are associated with complex arrangements of secondary extensional faults and SSE-verging folds; the kinematics of all structures are compatible with a top sense of shear to the SSE [1,2].

A N-dipping S3 cleavage is also sporadically developed throughout the Looe and South Devon basins [58] and is axial planar to a large-scale south-verging monoform that crops out across the peninsula towards the southern margin of the Looe Basin [20,21]. Its steeply inclined limb (Fig. 1), up to $5 \mathrm{~km}$ across and characterised by high strain secondary transposition fabrics, has been termed the Start-Perranporth Zone [47]. The association of steeply dipping foliations, containing rare E-W trending D1 mineral lineations and highly 
curvilinear D2 fold hinges, has been interpreted in terms of persistent convergence-related dextral transpression across a steeply inclined basement fault zone [47]. Nevertheless, field relations indicate that steeply dipping fabrics are primarily a result of the back rotation of gently S dipping D1 and high strain D2 fabrics during the D3 development of the monoform [20,21]. Whilst elements of D1 and D2 dextral transpression may be present, some 'oblique' D2 structures are a consequence of non-coaxial reorientation during D3. Rather than marking a major transpressional zone or convergence-related backfold, the Start-Perranporth Zone formed by top-to-the $\mathrm{S}$ extensional reactivation of a major out of sequence high strain D2 thrust zone, probably aided by forced folding above an extensionally reactivated basement fault [58]. Recalculated K-Ar whole-rock ages within this zone range from 315-292 Ma $[26,96]$.

Further north, D2 chevron folds that relate to the main episode of Culm Basin inversion are modified by southerly directed D3 simple shear [61]. The St Mellion 'Outlier' (Fig. 1) comprises Tournaisian rocks that were originally deposited on the southern margin of the Culm Basin; they were translated up to $22 \mathrm{~km}$ southwards on subhorizontal faults during postD2 gravitational collapse of the inverted Culm Basin [60].

There is a temporal progression, across the whole region, from gently dipping extensional faults, folds and cleavage (plastic-brittle) to higher angle brittle extensional faults that cross-cut earlier structures and are compatible with continued NNW-SSE extension [1,2]. These exert a fundamental control on outcrop geometry and can result in the cut-out of thrust faults that had previously undergone extensional reactivation, e.g. Lizard Boundary Fault, Carrick Thrust [1,2,6,72].

\subsection{Early Permian magmatism, mineralization and sedimentary basins}

The earliest onshore evidence for the development of post-Variscan sedimentary basins is in the Crediton Trough (Fig. 1), a $45 \mathrm{~km}$ long half graben controlled by thrust fault reactivation that predates emplacement of the Dartmoor Granite [29]. Deformed Culm Basin rocks (Namurian-Westphalian), exhumed from 6-7 km [96], are unconformably overlain by ?Stephanian-Sakmarian alluvial 'red-bed' sedimentary rocks (Exeter Group) that predate, and are intercalated, with basalts and lamprophyres yielding ${ }^{40} \mathrm{Ar}-{ }^{39} \mathrm{Ar}$ biotite ages between 290.8 $\pm 0.8 \mathrm{Ma}$ and $281.8 \pm 0.8 \mathrm{Ma}$ [29]. Offshore, to the south of the peninsula, the Western Approaches basins unconformably overlie the Variscan orogenic wedge [8,25,30,43]. The Plymouth Bay Basin contains up to $10 \mathrm{~km}$ of Permo-Triassic sedimentary rocks and is underlain by prominent zone of SE dipping seismic reflections that passes through the whole crust and into the mantle [8]. The lower two megasequences are ENE striking, overlain by 
bright reflectors interpreted as latest Carboniferous-Early Permian lavas similar to those onshore, and are considered to have formed by extensional reactivation of thrusts defining the orogenic wedge and upper plate [77].

The SW England Batholith extends at least $300 \mathrm{~km}$, from Dartmoor to west of the Scilly Isles; granitoids also occur further SW on the Goban Spur [24,30]. The batholith is hosted by the lower plate, in the immediate footwall of the orogenic wedge, and was emplaced during the Early Permian ( 295-270 Ma) [14]. Gravity modelling indicates plutons with a tabular form and a thickness of up to $9 \mathrm{~km}$, with deeper conduits to the south of the Dartmoor, Bodmin Moor and St Austell Granites [95]. Two mica, peraluminous, coarse-grained granite predominates and has initial ${ }^{87} \mathrm{Sr} /{ }^{86} \mathrm{Sr}$ ratios of $0 \cdot 710-0 \cdot 716$ and $\varepsilon_{\mathrm{Nd}}$ values of $-4 \cdot 7$ to $-7 \cdot 1$ [22]. A dominant lower crustal source is implied, but a mantle component has been inferred on the basis of whole-rock geochemistry, Sm-Nd isotope systematics [22], enclave compositions [93], a close spatial and temporal association with lamprophyres and basalts [56], and the helium isotope characteristics of inclusion fluids [90]. Emplacement post-dates the D3 plasticbrittle structures generated during the extensional reactivation of thrust faults $[1,2,54]$.

Magmatic fabrics are often compatible with moderate NW-SE extension of magma batches $[10,54,67]$. There is a clear spatial association between the granite batholith and W-As-Sn$\mathrm{Cu}-\mathrm{Zn}$ mineralisation [86]. Most mineral production was from tourmaline-quartz breccia veins ( $\mathrm{Sn}$ ) and chlorite-tourmaline-sulphide veins ( $\mathrm{Sn}, \mathrm{Cu}, \mathrm{As}, \mathrm{Zn}, \mathrm{Pb}$ ) [86]; in most areas these are hosted by steeply dipping extensional faults and/or tensile fractures that formed in response to continued NNW-SSE to N-S extension [88-90].

\section{Tectonic evolution}

\subsection{Rifting and passive margin development}

The non-marine sedimentary and associated igneous rocks of the Looe Basin (Dartmouth Group) indicate that rifting of normal thickness continental lithosphere had initiated by the late Lochkovian and had brought about sufficient thinning to form a south facing shallow marine shelf (Meadfoot Group) by the Pragian [58,60,65]. To the south, exhumation of the Lizard mantle peridotites probably also commenced in the early Devonian; the Traboe Cumulate Complex was emplaced, close to the base of the continental crust, and experienced rift-related granulite facies partial melting by the latest Emsian [16,18]. N-MORB basalts and dolerites (Landewednack Amphibolites) underwent high temperature metamorphism due to shear zone juxtaposition against exhumed mantle during the Eifelian [19,69]. Further north, early Eifelian T-MORB pillow lavas and radiolarian cherts deposited, formed in proximity to highly attenuated continental lithosphere (base Veryan Nappe and clasts within olistostrome). 
The above, and consideration of the onset of convergence, suggests that the distal passive margin reached its maximum width in the Eifelian, during formation of the Crousa Gabbro and dolerite dykes. Mylonitic fabrics in the mantle peridotites, Traboe Cumulate Complex, Landewednack-Porthoustock amphibolites and Crousa Gabbros, and the orientation of dolerite dykes, are all broadly consistent with (E)NE-(W)SW lithospheric extension during continental rifting, mantle exhumation and early sea-floor spreading $[3,18,19,41,75]$.

Asymmetrical extension in a non-volcanic margin setting, prior to the opening of a short-lived spreading centre has been proposed $[18,19]$. Such a model supports earlier suggestions that the Lizard ophiolite formed in a narrow oceanic basin, like the Red Sea [23] or Gulf of California [34], and has many similarities with Ligurian ophiolites [73]. There is no evidence of a supra-subduction zone (SSZ) setting [18,34,75]. The high temperature extensional deformation of the Crousa Gabbro [75], shear zone hosted Fe-Ti oxide gabbros [48], multiple dyke (magma) batches with distinct compositions [53,75], emplacement of gabbro and dolerite sheets in exhumed peridotite [3,75], juxtaposition of upper oceanic crust against exhumed mantle [19] and a relatively fertile spinel-plagioclase lherzolite with evidence of melt infiltration/melt-rock interaction $[18,23,50]$ are also features described from slow spreading ridges.

\subsection{Convergence}

The NW-directed thrusting of mantle peridotites over the Landewednack Amphibolites had commenced by the time syn-kinematic bimodal melts (Kennack Gneiss) were emplaced into the boundary zone. The continental crust source component of the felsic gneiss implies that mantle peridotite had been thrust over pre-rift continental lithosphere and/or syn-convergence sedimentary rocks [82], although they were not necessarily widely separated prior to the onset of convergence. Determinations of emplacement age vary from early Eifelian to late Frasnian $[17,69,82]$, whilst the lower age of syn-convergence amphibolite facies metamorphism is Famennian [80,82]. A clast of early Famennian granite (U-Pb zircon age of $373 \pm 6(2 \sigma) \mathrm{Ma}$ [28] within the Veryan Nappe olistostrome attests to at least local syn-convergence magmatism in the upper plate; the olistrostrome also hosts syn-convergent magmatic rocks [58]. Sedimentological and provenance data from the Gramscatho Group, and the geochronology of Lizard Complex magmatism and metamorphism, are consistent with the progressive, predominantly frontal, accretion of the distal passive margin during the Givetian to Famennian $[44,58]$.

The onset of continental collision was marked by the emergence of nappes comprising deep marine sedimentary and volcanic rocks (Carrick and Veryan nappes), oceanic 
lithosphere and pre-rift basement (Lizard nappe) and upper plate high-grade gneisses (Normannian Nappe) onto the northern passive margin by the earliest Carboniferous [44,58]. Deformation migrated through the passive margin during the Mississippian, inverting rift basins, including the southern part of the Carboniferous Culm Basin. The style of deformation, including the presence of facing confrontations, was strongly influenced by rift basin geometry [60]. The Culm Basin evolved from a rift basin to a Pennsylvanian thrust-top basin; its infill, derived from the east and then the north, indicating the influence of uplift caused by frontal thrusting and strike-slip along the Bristol Channel-Bray Fault [58]. 'Docking' with southern Britain resulted in late Westphalian D2 deformation across SW England and contemporaneous inversion of the Culm and North Devon basins.

\subsection{Extensional reactivation}

Variscan convergence across southern Britain ceased during the latest Carboniferous (c. 305 $300 \mathrm{Ma}$ ) and was post-dated by a NNW-SSE extensional regime (D3) that persisted through much of the Early Permian $[29,89]$. Early post-convergence extension brought about reactivation of the Rhenohercynian suture and subjacent D1/D2 thrust faults in the orogenic wedge and was associated with a dominant top sense of shear to the SSE [1,2]. Anomalous zones of steeply dipping primary/secondary cleavage, notably the 'Start-Perranporth Zone, were formed by D3 backfolding associated with thrust fault reactivation and forced folding above extensionally reactivated faults in pre-Devonian basement [58]. Significant extensional/erosional thinning and exhumation of the lower plate occurred prior to the initiation of Early Permian bimodal magmatism at c. 295 Ma. Whilst Variscan convergence brought about accretion and inversion of a thermally young passive margin, that increased the transient geothermal gradient within the lower plate, mantle derived melts underplated and/or injected during extension provided the heat to generate an anomalously large volume of granite over $25 \mathrm{Ma}[22,90]$. Steeply dipping fracture networks, in both granites and their host rocks, hosting magmatic-hydrothermal $\mathrm{Sn}-\mathrm{Cu}$ mineralization, reflect continued NNW-SSE extension until c. $275 \mathrm{Ma}$ [89]. The early infill of the Plymouth Bay Basin formed above the subsiding upper plate during extensional reactivation of the Rhenohercynian suture [77].

\section{Wider implications and unresolved issues}

The Upper Palaeozoic geological evolution of SW England provides important constraint on Variscan tectonic models due to its location between Avalonia and Armorica, and hence proximity to the Rhenohercynian and Rheic suture(s). There are strong similarities with mainland Europe, where late Devonian convergence along the active northern margin of the 
Saxothuringian Zone (Mid-German Crystalline High) resulted in continental collision and progressive inversion of the Devonian (Rhenohercynian) passive margin during the Carboniferous $[38,70]$. The westwards correlation of the Rhenohercynian suture, across the Bristol Channel-Bray Fault, to SW England appears justified $[38,45,62]$. The Rheic suture is also placed immediately south of SW England and is coincident with the Rhenohercynian suture in most tectonic reconstructions e.g. $[62,64,97]$. However, limited knowledge of both the pre-Devonian geology of SW England, and hence its Avalonian affinities, and the prePermian offshore geology between Britain and France results in considerable uncertainty. These and other outstanding issues are discussed below.

\subsection{Is SW England part of Avalonia?}

SW England (Fig. 6) is bounded, offshore to the south, by a reactivated late Devonian Rhenohercynian suture with the upper plate Normannian Terrane, and to the north and east by the Bristol Channel-Bray Fault [25] that brought about late Westphalian juxtaposition against unequivocal Avalonian lithosphere [58]. There are no Lower Palaeozoic palaeobiogeographical or palaeomagnetic data for SW England. The only exposed preDevonian rocks, the Man of War Gneiss and Old Lizard Head Formation (Lizard Complex), have late Cambrian arc affinities characteristic of peri-Gondwanan terranes $[68,81]$ but it is unclear whether they are derived from the lower or upper plate.

Lower plate crust was indirectly sampled, and mixed with a juvenile mantle-derived component, during formation of the Kennack Gneiss (granitic facies) that has $\varepsilon_{\mathrm{Nd}}(376 \mathrm{Ma})$ values of +0.7 to -3.0 and $\mathrm{T}_{\mathrm{DM}}$ model ages of $849-1266 \mathrm{Ma}$ [82]; individual zircons range from $490 \mathrm{Ma}$ to $>1700 \mathrm{Ma}$ [69]. The Early Permian SW England granites also indirectly sample lower plate crust and have $\varepsilon_{\mathrm{Nd}}(290 \mathrm{Ma})$ values of -4.7 to -7.1 and $\mathrm{T}_{\mathrm{DM}}$ model ages of 1271-1788 Ma [22]. The zircon data from the Kennack Gneiss indicate a significant Mesoproterozoic source component, typical of Avalonian basement [79] and the $\mathrm{T}_{\mathrm{DM}}$ model ages from both the Kennack Gneiss and SW England granites are compatible with this (dependent upon the proportion of admixed juvenile mantle-derived component). However the age corrected $\varepsilon_{\mathrm{Nd}}$ values for the Kennack Gneiss and, in particular, the SW England granites are rather more negative than typical Avalonian basement and overlap with values for Armorica/Saxothuringia [68].

North and east of the Bristol Channel-Bray Fault, rocks of Avalonian affinity form the majority of the lower plate [38]. SW England occupies a similar position, north of the Rheic and/or Rhenohercynian suture(s), and hence also probably represents the southern margin of 
Avalonia. However, as no data unambiguously confirm the presence of Avalonian basement, a pre-Devonian origin as a separate Gondwana-derived terrane cannot be excluded [25].

\subsection{What is the affinity of the upper plate (Normannian Terrane)?}

The upper plate Normannian Terrane is largely confined to the English Channel (Fig. 6) and hence is poorly constrained. The only exposure along its northern margin is the garnetiferous granite gneiss of Eddystone Rock that has a Frasnian K-Ar biotite cooling age [66]. Exploration well 87/12-1A, located $55 \mathrm{~km} \mathrm{SE}$ of the Lizard, penetrated $479 \mathrm{~m}$ of Middle Devonian strata that was dominated by Givetian limestone and overlain by a 'shallow water' siliciclastic succession [30]. Clasts within the southerly derived Gramscatho Basin olistostromes (section 3.1) provide additional data. Ordovician quartzites have an undisputed Armorican fauna [78]. A greywacke (presumed resedimented) has yielded a laser-probe ${ }^{40} \mathrm{Ar}-$ ${ }^{39} \mathrm{Ar}$ whole-rock plateau age of $415 \pm 2 \mathrm{Ma}$ (Pridoli) [15] and is similar to the ${ }^{40} \mathrm{Ar}-{ }^{39} \mathrm{Ar}$ whole-rock plateau age of 420-410 Ma (Ludlow-Pridoli) obtained from a cleaved metasiltstone clast [32]. Gramscatho Group sandstones in the Carrick Nappe (Portscatho Fomation) indicate a dominant continental magmatic arc source and have $\varepsilon_{\mathrm{Nd}}(370 \mathrm{Ma})$ values of -4.3 to -10.3 and $\mathrm{T}_{\mathrm{DM}}$ model ages between 1177-1658 Ma [35]. Two granite clasts, with volcanic arc or syncollisional geochemistries, have yielded magmatic $\mathrm{U}-\mathrm{Pb}$ zircon ages of $422 \pm 4(2 \sigma) \mathrm{Ma}$ (Ludlow) and $373 \pm 6(2 \sigma) \mathrm{Ma}$ (early Famennian); upper discordia intercept ages of $2445 \mathrm{Ma}$ and $2606 \mathrm{Ma}$ suggest a late Archean or early Proterozoic source component [28].

The southern margin of the Normannian Terrane may be represented by the Léon Domain in northern Brittany $[31,85,92]$. These rocks have affinities with the Saxothuringian Zone and have undergone Variscan deformation and metamorphism [85]. Partially retrogressed eclogites, derived from N-MORB, may have been metamorphosed as early as $439 \pm 12 \mathrm{Ma}$ (early Silurian), but possibly later [85].

The above data indicate that the Normannian Terrane probably originated as part of the Armorican Terrane Assemblage. Clasts sourced from its northern margin, in the Upper Devonian, also suggest Ludlow and Famennian continental arc magmatism and LudlowPridoli cleavage development $[15,28,32]$. These data are limited and could reflect either discrete magmatic / deformation episodes or incomplete sampling of more or less continuous magmatism and accretion-related deformation. In addition, the possibility that some source components might be derived from accreted lower plate material cannot be excluded.

However, east of the Bristol Channel-Bray Fault, data from the Mid-German Crystalline High are more abundant and compatible with separate episodes of Silurian and late Devonian- 
Carboniferous continental arc magmatism [38]. Middle Devonian limestones in the upper part of the Normannian Terrane (well 87/12-1A) are also matched by limestones of similar age overlying arc rocks of the Mid-German Crystalline High in Germany (Saar 1 borehole) $[38,45]$.

Although the Normannian/Léon Terrane originated as part of the Armorican Terrane Assemblage, it might not have been a contiguous part of Armorica sensu stricto during the Silurian-Devonian. The Léon Domain eclogites have been variably interpreted as: (i) the remnants of an oceanic area separating the Normannian/Léon Terrane from Armorica [31], or (ii) remnants of the Rheic Ocean [85,92]. Similar ambiguities occur east of the Bristol Channel-Bray Fault where the Vesser Rift separated the Mid-German Crystalline High from the remainder of the Saxothuringian Zone to the south [51].

\subsection{The SW England Rhenohercynian passive margin and the Rheic Ocean}

The relationship between the development and subsequent inversion of the Rhenohercynian passive margin and the closure of the Rheic Ocean is poorly constrained (Fig. 7). The Rhenohercynian and Rheic sutures could be: (A) temporally and spatially coincident, i.e. the Rhenohercynian passive margin represented the northern margin of the Rheic Ocean e.g. [31], (B) spatially coincident but temporally separated, i.e. the Rhenohercynian passive margin formed in a successor basin after the closure of the Rheic Ocean [38], or (C) spatially \pm temporally separated, i.e. the Rhenohercynian passive margin developed in a marginal basin to the Rheic Ocean e.g. [92].

Model A is considered unlikely. SW England provides evidence for the LochkovianEifelian development of a passive margin associated with an incipient or small ocean (section 6.1). It is difficult to reconcile these data with interpretation of the Lizard ophiolite as a: (i) late formed segment of Rheic Ocean (ridge push forces should suppress coeval rifting of the adjacent passive margin; the Rheic passive margin should have developed much earlier), or (ii) oceanic crust formed in a forearc setting above the subducting Rheic Ocean (no indication of supra-subduction zone geochemistry).

In Model B, Rhenohercynian rifting occurred close to a late Silurian-earliest Devonian suture between Eastern Avalonia and the Armorican Terrane Assemblage that resulted from northwards subduction and closure of the Rheic Ocean [38]. One possible expression of Silurian northwards-directed subduction of the Rheic Ocean below southern Britain is the EW trending zone of Llandovery intraplate magmatism (Fig. 6) that occurs north and south of the Variscan Front [71]. It might conceivably represent the northern margin of a short-lived early Silurian back arc rift. Any associated upper plate magmatic arc would be hidden below 
the post-Silurian cover of SW England. The Ludlow-Pridoli regional metamorphism [15,32] and magmatism [28] inferred from the Normannian Terrane might record its Silurian ?oblique accretion to SW England but the magmatism would also require southwards subduction of Rheic Ocean below the Normannian Terrane. If the Normannian Terrane was a contiguous part of the Armorican Terrane Assemblage, the Rheic Ocean closed during this event.

In Model C, the Rhenohercynian passive margin developed in a marginal basin setting to the Rheic Ocean. There are two possibilities. Model C1 is a modification of Model B where the Normannian Terrane was not a contiguous part of the Armorican Terrane Assemblage. Continued northwards subduction of the Rheic Ocean outboard (south) of the accreted Normannian Terrane was accompanied by slab roll back and upper plate extension. In this scenario, the Rheic suture would be preserved within the Léon Domain, e.g. [85,92]. In Model $\mathrm{C} 2$, the Rhenohercynian marginal basin formed entirely within the southern Avalonian margin, as a consequence of slab pull forces established following southwards subduction of the Rheic Ocean ridge [92]. In these models, marginal basin (Lizard) oceanic lithosphere is separated by a narrow strip of either Armorican (C1) or Avalonian (C2) continental lithosphere from the closing Rheic Ocean further south.

All of the remaining models $(\mathrm{B}, \mathrm{C} 1, \mathrm{C} 2)$ are broadly admissible with available data from SW England (Fig. 7), although numerous details are necessarily speculative. No model accounts for all aspects and there are presently insufficient data to adequately test between them. Most palaeogeographical reconstructions consider a faunal barrier, implied to be the narrowed Rheic Ocean, persisted between Armorica and Avalonia during the Early Devonian e.g [64], which would mitigate against Model B. Early Devonian palaeomagnetic poles from South Wales (Lat. $7^{\circ} \mathrm{S}$, Long. $307^{\circ} \mathrm{E}$ ) [13] and northern Armorica (Lat. $13{ }^{\circ} \mathrm{S}$, Long. $315^{\circ} \mathrm{E}$ ) [94] (but see also [74]) suggest a separation of $\sim 1100 \mathrm{~km}$ at the onset of Rhenohercynian rifting. Whilst the Normannian Terrane has Armorican affinities that would support Model $\mathrm{C} 1$, the possibility that Avalonian crust from the southern side of the Rhenohercynian marginal basin (Model C2) was accreted to, or subducted below it, during closure of the Rheic Ocean [92] cannot be precluded. Indeed, the $\varepsilon_{\mathrm{Nd}}$ data and and $\mathrm{T}_{\mathrm{DM}}$ model ages for lower plate SW England granites and upper plate sourced Gramscatho Group sandstones are very similar. These outstanding issues will be best addressed through more widespread application of $\mathrm{U}-\mathrm{Pb}$ zircon dating provenance methods to clasts from the Gramscatho Basin olistostromes.

(E)NE-(W)SW extension, implied by Lizard Complex mantle peridotite fabrics and dyke orientations, is oblique to the E-W trending Rhenohercynian Zone and has been used to infer a dextral transform origin for Model A $[7,18,19]$ that could also be applied to models B 
and C. However, this model contrasts with the orthogonal rift geometry implied by the development of the passive margin further north [58]. Palaeomagmetic relations are ambiguous [42] and the possibility of vertical axis rotation of the entire Lizard Complex, prior to final emplacement, is a possibility in view of an apparent $35^{\circ}$ clockwise rotation with respect to remanent magnetisation within rocks of similar age to the north, e.g. [9].

\subsection{Processes causing rifting}

Development of the SW England passive margin represents two or three tectonic episodes. Lochkovian to Emsian rifting was followed by a short period of sea-floor spreading within the Emsian-Eifelian. Its duration may have been only $10 \mathrm{Ma}$, but even at a very slow spreading rate of $20 \mathrm{~mm} \mathrm{yr}^{-1}$ could still have generated $\sim 200 \mathrm{~km}$ of ocean floor. The Emsian hiatus within the Staddon Formation (Section 2.3) may reflect the onset of sea-floor spreading. Ridge push forces generated during this short interval may have contributed towards Acadian deformation [97] north of Variscan Front but this appears slightly younger and would also require deformation to have been effectively be partitioned away from the passive margin. Subsequent late Eifelian to Famennian rifting was coeval with convergence further south and may have been driven by slab pull following subduction of the Lizard ocean ridge. Riftrelated magmatism and basin formation persisted in the lower plate to the Visean [58]. The reason for this is unclear. Convergence, following initial accretion of the distal passive margin may have been punctuated by slab detachment, e.g. [84].

\subsection{Significance of Bristol Channel-Bray Fault}

The Bristol Channel-Bray Fault is a major structure in the northern Variscides [45]. A dextral displacement of up to several hundred $\mathrm{km}$ during the Carboniferous can account for the absence of Acadian (Eifelian) deformation in SW England [97] and the anomalous provenance of Late Carboniferous foreland successions [91]. It may also account for alongstrike variations in the Rhenohercynian Zone. The SW England passive margin is somewhat narrower than in Germany, and this might be due to its excision along the fault [97]. The generation and anomalous thickness of the Cornubian Batholith was strongly influenced by extensional reactivation of the Rhenohercynian suture and footwall, possibly during dextral transtensional between the NW-SE trending Bristol Channel-Bray Fault and the Pyrenean Fault [4]. 


\section{Conclusions}

1) The SW England Rhenohercynian lower plate passive margin developed during Lochkovian-Eifelian rifting. Evidence for pre-rift Avalonian basement is equivocal and SW England may represent a separate Lower Palaeozoic terrane.

2) The Lizard ophiolite preserves exhumed mantle and early-formed oceanic crust (probably Eifelian) that is compatible with formation of a small ocean basin. It is unlikely to represent a fragment of Rheic Ocean or associated forearc (SSZ) ocean crust.

3) The upper plate, represented by the Normannian/Léon Terrane, has Armorican affinities and can be correlated with the Mid-German Crystalline High of the Saxothuringian Zone. It may have previously docked with SW England in the Silurian.

4) The Rhenohercynian passive margin probably developed within a marginal basin north of the Rheic Ocean or, possibly, a successor basin following its closure. The Rheic and Rhenohercynian sutures may be coincident, or the Rheic suture may be located further south in the Léon Domain. There is presently insufficient data to test between these models.

5) Convergence initiated in the late Eifelian, following closure of the Rheic Ocean, and included the Upper Devonian frontal accretion of elements of the distal passive margin. Collision was accompanied by inversion of the passive margin basins and was strongly influenced by rift basin geometry, resulting in local facing confrontations.

6) Juxtaposition of SW England with southern Britain occurred during dextral displacement on the Bristol Channel-Bray Fault during Carboniferous convergence.

7) Latest Carboniferous-Early Permian extensional reactivation of the suture and accretionary wedge brought about thinning and exhumation of the lower plate and was accompanied by bimodal magmatism, including the generation and emplacement of the $400 \mathrm{~km}$ Cornubian Batholith. Upper plate sedimentary basins were developed coevally above the reactivated suture.

\section{Acknowledgements}

Karel Schulmann for encouraging our participation in the Orleans meeting and this volume. Martin Holder made a significant contribution to developing our understanding of SW England passive margin evolution. Wolfgang Franke has provided inspiration and hospitality in Germany over the last 25 years. Duncan Pirrie and Peter Frost provided support in Scotland during writing. Thanks to Rob Strachan and Nigel Woodcock for constructive reviews. This paper is published with the approval of the Executive Director of the British Geological Survey (NERC). 


\section{References}

[1] A.C. Alexander, R.K. Shail, Late Variscan structures on the coast between Perranporth and St. Ives, south Cornwall, Proc. Ussher Soc. 8 (1995) 398-404.

[2] A.C. Alexander, R.K. Shail, Late- to post-Variscan structures on the coast between Penzance and Pentewan, south Cornwall, Proc. Ussher Soc. 9 (1996) 72-78.

[3] S. Allerton, C.J. Macleod, Fault-controlled magma transport through the mantle lithosphere at slow-spreading ridges, in: R.A. Mills, K. Harrison (Eds.), Modern ocean floor processes and the geological record, Geol. Soc. Lond. Spec. Publ. 148 (1998) 29-42.

[4] F. Arthaud, P. Matte, Late-Palaeozoic strike-slip faulting in southern Europe and northern Africa: result of a right lateral shear zone between the Appalachians and the Urals, Bull. Geol. Soc. Am. 88 (1977) 1305-1320.

[5] R.P. Barnes, Possible Lizard-derived material in the underlying Meneage Formation, J. Geol. Soc. Lond. 141 (1984) 79-85.

[6] R.P. Barnes, J.R. Andrews, Hot or cold emplacement of the Lizard Complex? J. Geol. Soc. Lond. 141 (1984) 37-40.

[7] R.P. Barnes, J.R. Andrews, Upper Palaeozoic ophiolite generation and obduction in south Cornwall, J. Geol. Soc. Lond.143 (1986) 117-124.

[8] BIRPS, ECORS, Deep seismic reflection profiling between England, France and Ireland, J. Geol. Soc. Lond. 143 (1986) 45-52.

[9] British Geological Survey, Land's End, Sheet $50^{\circ} \mathrm{N}-06^{\circ} \mathrm{W}, 1: 250000$ Series, British Geological Survey, Nottingham, UK, 1985.

[10] J.L. Bouchez, T. Mintsa Mi Nguema, L. Esteban, R. Siqueira, R. Scrivener, The tourmaline-bearing granite pluton of Bodmin (Cornwall, UK): magnetic fabric study and regional inference, J. Geol. Soc. Lond. 163 (2006) 607-616.

[11] A.V. Bromley, Ophiolitic origin of the Lizard Complex, J. Camb. Sch. Mines 79 (1979) 25-38.

[12] M. Brooks, J.J. Doody, F.R.J. Al-Rawi, Major crustal reflectors beneath SW England, J. Geol. Soc. Lond. 141 (1984) 97-103.

[13] J.E.T. Channell, C. McCabe, N.H. Woodcock, Early Devonian (pre-Acadian) magnetization directions in Lower Old Red Sandstone of south Wales (UK), Geophys. J. Int. 108 (1992) 883-894.

[14] Y. Chen, A.H. Clark, E. Farrar, H.A.H.P. Wasteneys, M.J. Hodgson, A.V. Bromley, Diachronous and independent histories of plutonism and mineralization in the Cornubian Batholith, southwest England, J. Geol. Soc. Lond. 150 (1993) 1183-1191. 
[15] A.H. Clark, H.A. Sandeman, C. Liu, D.J. Scott, E. Farrar, D.A. Archibald, A.V. Bromley, K.A. Jones, L.N. Warr, An emerging geochronological record of the construction and emplacement of the Lizard ophiolite, SW Cornwall, Geoscience in south-west England 9 (1998) 276-277.

[16] A.H. Clark, D.J. Scott, H.A. Sandeman, A.V. Bromley, E. Farrar, Siegenian generation of the Lizard ophiolite: U-Pb zircon age data for plagiogranite, Porthkerris, Cornwall, J. Geol. Soc. Lond. 155 (1998) 595-598.

[17] A.H. Clark, H.A. Sandeman, A.P. Nutman, D.H. Green, A. Cook, Discussion on SHRIMP U-Pb zircon dating of the exhumation of the Lizard Peridotite and its emplacement over crustal rocks: constraints for tectonic models, J. Geol. Soc. Lond. 160 (2003) 331-335. [18] C.A. Cook, R.E. Holdsworth, M.T. Styles, J.A. Pearce, Pre-emplacement structural history recorded by mantle peridotites: an example from the Lizard Complex, SW England, J. Geol. Soc. Lond. 157 (2000) 1049-1064.

[19] C.A. Cook, R.E. Holdsworth, M.T. Styles, The emplacement of peridotites and associated oceanic rocks from the Lizard Complex, southwest England, Geol. Mag. 139 (2002) 27-45.

[20] M.P. Coward, K.R. McClay, Thrust tectonics of S Devon, J. Geol. Soc. Lond. 140 (1983) 215-228.

[21] M.P. Coward, S. Smallwood, An interpretation of the Variscan tectonics of SW Britain, in: D.H. Hutton, D.J. Sanderson (Eds.), Variscan Tectonics of the North Atlantic Region, Geol. Soc. Lond. Spec. Publ. 14 (1984) 89-102.

[22] D.P.F. Darbyshire, T.J. Shepherd, Nd and Sr isotope constraints on the origin of the Cornubian batholith, SW England, J. Geol. Soc. Lond. 151 (1994) 795-802.

[23] G.R. Davies, Isotopic evolution of the Lizard Complex, J. Geol. Soc. Lond. 141 (1984) $3-14$.

[24] G.A. Day, C.A. Williams, Gravity compilation in the NE Atlantic and interpretation of gravity in the Celtic Sea. Earth. Planet. Sci. Lett. 8 (1970) 205-213.

[25] G.A. Day, J.W.F. Edwards, R.R. Hillis, Influences of Variscan structures off southwest Britain on subsequent phases of extension, in: A.J. Tankard, H.R. Balkwill (Eds.), Extensional tectonics and stratigraphy of the North Atlantic Margins, Mem. Am. Assoc. Pet. Geol. 46 (1989) 425-432.

[26] H.R. Dodson, D.C. Rex, Potassium-argon ages of slates and phyllites from south-west England, Q. J. Geol. Soc. Lond. 126 (1971) 464-499.

[27] J.J. Doody, M. Brooks, Seismic refraction investigation of the structural setting of the Lizard and Start complexes, SW England, J. Geol. Soc. Lond. 143 (1986) 135-140. 
[28] W. Dorr, P.A. Floyd, B.E. Leveridge, U-Pb ages and geochemistry of granite pebbles from the Devonian Menaver Conglomerate, Lizard peninsula: provenance of Rhenohercynian flysch of SW England, Sed. Geol. 124 (1999) 131-147.

[29] R.A. Edwards, G. Warrington, R.C. Scrivener, N.S. Jones, H.W. Haslam, L. Ault, The Exeter Group, south Devon, England: a contribution to the early post-Variscan stratigraphy of northwest Europe, Geol. Mag. 134 (1997) 177-197.

[30] C.D.R. Evans, The geology of the western English Channel and its western approaches, British Geological Survey, HMSO, London, UK, 1990, 93 p.

[31] M. Faure, E. Bé Mézème, M. Duguet, C. Cartier, J.-Y. Talbot, Paleozoic tectonic evolution of medio-Europa from the example of the French Massif Central and Massif Armoricain, J. Virtual Explorer, 19 (2005), Paper 5.

[32] F.J. Fitch, S.C. Forster, J.A. Miller, The ${ }^{40} \mathrm{Ar} /{ }^{39} \mathrm{Ar}$ spectrum of a rock from Gerrans Bay, Cornwall, J. Geol. Soc. Lond. 141 (1984) 21-25.

[33] P.A. Floyd, Geochemical characteristics and comparison of the basic rocks of the Lizard Complex and basaltic lavas within the Hercynian troughs of SW England, J. Geol. Soc. Lond. 141 (1984) 61-70.

[34] P.A. Floyd, Igneous activity, in: R.D. Dallmeyer, W. Franke, K. Weber (Eds.), PrePermian geology of Central and Eastern Europe, Springer-Verlag, Berlin, 1995, pp. 59-81. [35] P.A. Floyd, R. Shail, R., B.E. Leveridge, W. Franke, Geochemistry and provenance of Rhenohercynian synorogenic sandstones: implications for tectonic environment discrimination, in: A.C. Morton, S.P. Todd, P.D.W. Haughton (Eds.), Developments in Sedimentary Provenance Studies, Geol. Soc. Lond. Spec. Publ. 57 (1991) 173-188. [36] P.A. Floyd, R.E. Holdsworth, S.A. Steele, Geochemistry of the Start Complex greenschists: Rhenohercynian MORB?, Geol. Mag. 130 (1993) 345-352.

[37] P.A. Floyd, C.S. Exley, M.T. Styles, Igneous Rocks of South-West England, Geological Conservation Review Series, Chapman and Hall, London, UK, 1993, 268 p.

[38] W. Franke, The mid-European segment of the Variscides: tectonostratigraphic units, terrane boundaries and plate tectonic evolution, in: W. Franke, V. Haak, O. Oncken, D. Tanner (Eds.), Orogenic processes: Quantification and modelling in the Variscan Belt, Geol. Soc. Lond. Spec. Publ. 179 (2000) 35-61.

[39] A.J.J. Goode, R.J. Merriman, Evidence of crystalline basement west of the Land's End granite, Proc. Geol. Ass. 98 (1987) 39-43.

[40] A.J.J. Goode, R.J. Merriman, D.P.F. Darbyshire, Evidence of crystalline basement west of the Land's End granite, Cornwall: a reply, Proc. Geol. Ass. 98 (1987) 272. 
[41] W. Gibbons, L. Thompson, Ophiolitic mylonites in the Lizard Complex: ductile extension in the lower oceanic crust, Geology 19 (1991) 1009-1012.

[42] E.A. Hailwood, P.J.R. Gash, P.C. Andresen, J.P.N. Badham, Palaeomagnetism of the Lizard Complex, SW England, J. Geol. Soc. Lond. 141 (1984) 27-35.

[43] R.R. Hillis, T.J. Chapman, Variscan structure and its influence on post-Carboniferous basin developmant, Western Approaches Basin, SW UK Continental Shelf, J. Geol. Soc. Lond. 149 (1992) 413-417.

[44] M.T. Holder, B.E. Leveridge, A model for the tectonic evolution of south Cornwall, J. Geol. Soc. Lond. 143 (1986) 125-134.

[45] M.T. Holder, B.E. Leveridge, Correlation of the Rhenohercynian Variscides, J. Geol. Soc. Lond. 143 (1986) 141-147.

[46] M.T. Holder, B.E. Leveridge, A framework for the European Variscides, Tech. Rept. British Geological Survey, WA/94/24 UK, 1994, 53 p.

[47] R.E. Holdsworth, The Start-Perranporth line: a Devonian terrane boundary in the Variscan orogen of SW England, J. Geol. Soc. Lond. 146 (1989) 419-421.

[48] L. Hopkinson, S. Roberts, Ridge axis deformation and coeval melt migration within layer 3 gabbros: evidence from the Lizard Complex, UK, Contrib. Mineral. Petrol. 121 (1995) 126138.

[49] K.A. Jones, Deformation and emplacement of the Lizard Ophiolite Complex, SW England, based on evidence from the Basal Unit, J. Geol. Soc. Lond. 154 (1997) 871-885. [50] K. Kadoshima, S. Arai, Chemical analysis of detrital chromian spinels from the Lizard area, Cornwall, England: an attempt for lithological and petrological survey of the Lizard peridotite, N. Jb. Miner. Mh. 5 (2001) 193-209.

[51] H. Kemnitz, R.L.Romer, O. Oncken, Gondwana break-up and the northern margin of the Saxothuringian belt (Variscides of Central Europe), Int. J. Earth Sciences 91 (2002) 246-259. [52] G.A. Kirby, The Lizard Complex as an ophiolite, Nature 282 (1979) 58-61.

[53] G.A. Kirby, The petrology and geochemistry of dykes of the Lizard Ophiolite Complex, Cornwall, J. Geol. Soc. Lond. 141 (1984) 53-59.

[54] Z. Kratinova, K. Schulmann, F. Hrouda, R.K. Shail, The role of regional tectonics and magma flow coupling versus magmatic processes in generating contrasting magmatic fabrics within the Land's End granite, Cornwall, Geoscience in South-West England 10 (2003) 442448.

[55] R.C. Leake, M.T. Styles, Borehole sections through the Traboe hornblende schists, a cumulate complex overlying the Lizard peridotite, J. Geol. Soc. Lond. 141 (1984) 41-52. 
[56] P.T. Leat, R.N. Thompson, M.A. Morrison, G.L. Hendry, S.C. Trayhorn, Geodynamic significance of post-Variscan intrusive and extrusive potassic magmatism in SW England, Trans. R. Soc. Edinburgh: Earth Sci. 77 (1987) 349-360.

[57] B.E. Leveridge, M.T. Holder, G.A. Day, Thrust nappe tectonics in the Devonian of south Cornwall and the western English Channel, in: D.H. Hutton, D.J. Sanderson (Eds.), Variscan Tectonics of the North Atlantic Region, Geol. Soc. Lond. Spec. Publ. 14 (1984) 103-112. [58] B.E. Leveridge, A.J. Hartley, The Variscan Orogeny: the development and deformation of Devonian/Carboniferous basins in SW England and South Wales, in: P.J. Brenchley, P.F. Rawson (Eds.), The Geology of England and Wales, Geological Society, London, UK, 2006, pp. 225-255.

[59] B.E. Leveridge, M.T. Holder, A.J.J. Goode, Geology of the country around Falmouth, Memoir of the British Geological Survey, HMSO, London, UK, 1990, 70 p.

[60] B.E. Leveridge, M.T. Holder, A.J.J. Goode, R.C. Scrivener, N.S. Jones, R.J. Merriman, The Plymouth and Southeast Cornwall Area - A Concise Account of Geology, Memoir of the British Geological Survey, HMSO, London, UK, 2002, 143 p.

[61] G.E. Lloyd, N. Chinnery, The Bude Formation, SW England - A three-dimensional, intra-formational Variscan inbricate stack? J. Struct. Geol. 24 (2002) 1259-1280.

[62] P. Matte, The Variscan collage and orogeny (480-290 Ma) and the tectonic definition of the Armorican microplate: a review, Terra Nova 13 (2001) 122-128.

[63] S.C. Matthews, The Variscan fold belt in southwest England, N. Jb. Geol. Paläont. Abh. 154 (1977) 94-127.

[64] W.S. McKerrow, C. Mac Niocaill, P.E. Ahlberg, G. Clayton, C.J. Cleal, R.M.C. Eagar, The Late Palaeozoic relations between Gondwana and Laurussia, in: W. Franke, V. Haak, O. Oncken, D. Tanner (Eds.), Orogenic processes: Quantification and modelling in the Variscan Belt, Geol. Soc. Lond. Spec. Publ. 179 (2000) 9-20.

[65] R.J. Merriman, J.A. Evans, B.E. Leveridge, Devonian and Carboniferous volcanic rocks associated with the passive margin sequences of SW England; some geochemical perspectives, Proc. Ussher Soc. 10 (2000) 77-85.

[66] J.A. Miller, D.H. Green, Age determinations of rocks in the Lizard (Cornwall) area, Nature 192 (1961) 1175-1176.

[67] T. Mintsa Mi Nguema, R.I.F. Trindade, J.L. Bouchez, P. Launeau, Selective thermal enhancement of magnetic fabrics from the Carnmenellis granite (British Cornwall), Phys. Chem. Earth 27 (2002) 1281-1287. 
[68] J.B. Murphy, G. Gutierrez-Alonso, R.D. Nance, J. Fernandez-Suarez, J.D. Keppie, C. Quesada, R.A. Strachan, J. Dostal, Origin of the Rheic Ocean: Rifting along a Neoproterozoic suture? Geology 34 (2006) 325-328.

[69] A.P. Nutman, D.H. Green, C.A. Cook, M.T. Styles, R.E. Holdsworth, SHRIMP U-Pb zircon dating of the exhumation of the Lizard Peridotite and its emplacement over crustal rocks: constraints for tectonic models, J. Geol. Soc. Lond. 158 (2001) 809-820.

[70] O. Oncken, A. Plesch, J. Weber, W. Ricken, S. Schrader, Passive margin detachment during arc continent collision, in: W. Franke, V. Haak, O. Oncken, D. Tanner (Eds.), Orogenic processes: Quantification and Modelling in the Variscan Belt, Geol. Soc. Lond. Spec. Publ. 179 (2000) 199-216.

[71] T.C. Pharaoh, R.J. Merriman, J.A. Evans, T.S. Brewer, P.C. Webb, N.J.P. Smith, Early Palaeozoic arc-related volcanism in the concealed Caledonides of southern Britain, Ann. Soc. Géol. Belg. 114 (1991) 63-91.

[72] M.R. Power, A.C. Alexander, R.K. Shail, P.W. Scott, A re-interpretation of the internal structure of the Lizard Complex, Proc. Ussh. Soc. 9 (1996) 63-67.

[73] E. Rampone, G. Piccardo, The ophiolite-oceanic lithosphere analogue: new insights from the northern Apennines (Italy), in: Y. Dilek, E.M. Moores, D. Elthon, A. Nicholas (Eds.), Ophiolites and oceanic crust: New insights from field studies and the Ocean Drilling Project, Geol. Soc. Am. Sp. Paper 349 (2000) 21-34.

[74] M. Robardet, F.Paris, Y. Plusquellec, J. Tait, Comment and reply on "New Early Devonian paleomagnetic data from NW France: Paleogeography and implications for the Armorican microplate hypothesis by J. Tait, J. Geophys. Res. B106 (2001) 13,307-13,313. [75] S. Roberts, J.R. Andrews, J.M. Bull, D.J. Sanderson, Slow-spreading ridge-axis tectonics: evidence from the Lizard complex, UK, Earth Planet. Sci. Lett. 116 (1993) 101112.

[76] K.E. Rollin, Geophysical surveys on the Lizard Complex, Cornwall, J. Geol. Soc. Lond. 143 (1986) 437-46.

[77] A. Ruffell, M.P. Coward, M. Harvey, Geometry and tectonic evolution of megasequences in the Plymouth Bay Basin, English Channel, in: S.A.R. Boldy (Ed.), Permian and Triassic Rifting in Northwest Europe, Geol. Soc. Lond. Spec. Publ. 91 (1995) 193-214. [78] P.M. Sadler, Trilobites from the Gorran Quartzites, Ordovician of south Cornwall, Palaeontology 17 (1974) 71-93.

[79] S.D. Samson, R.S. D’Lemos, B.V. Miller, M.A. Hamilton, Neoproterozoic palaeogeography of the Cadomia and Avalon terranes: constraints from detrital zircon $\mathrm{U}-\mathrm{Pb}$ ages, J. Geol. Soc. Lond. 162 (2005) 65-71. 
[80] H.A. Sandeman, Y. Chen, A.H. Clark, E. Farrar, Constraints on the P-T conditions and age of emplacement of the Lizard ophiolite, Cornwall: amphibole-plagioclase thermobarometry and ${ }^{40} \mathrm{Ar} /{ }^{39} \mathrm{Ar}$ geochronology of basal amphibolites, Can. J. Earth Sci. 32 (1995) 261-272.

[81] H.A. Sandeman, A.H. Clark, M.T. Styles, D.J. Scott, J.G. Malpas, E. Farrar, Geochemistry and U-Pb and ${ }^{40} \mathrm{Ar}-{ }^{39} \mathrm{Ar}$ geochronology of the Man of War Gneiss, Lizard Complex, SW England: pre-Hercynian arc-type crust with a Sudeten-Iberian connection, J. Geol. Soc. Lond. 154 (1997) 403-417.

[82] H.A. Sandeman, A.H. Clark, D.J. Scott, J.G. Malpas, The Kennack Gneiss of the Lizard Peninsula, Cornwall, SW England: commingling and mixing of mafic and felsic magmas accompanying Givetian continental incorporation of the Lizard ophiolite, J. Geol. Soc. Lond. 157 (2000) 1227-1242.

[83] D.J. Sanderson, Structural variation across the northern margin of the Variscides of NW Europe, in: D.H.W. Hutton, D.J. Sanderson (Eds.), Variscan Tectonics of the North Atlantic Region, Geol. Soc. Lond. Sp. Publ. 14 (1984) 149-165.

[84] A. Schoonmaker, W.S.F. Kidd, D.C. Bradley, Foreland-forearc collisional granitoid and mafic magmatism caused by lower-plate lithospheric slab breakoff: The Acadian of Maine, and other orogens, Geology 33 (2005), 961-964.

[85] B. Schulz, E. Krenn, F. Finger, H. Brätz, R. Klemd, Cadomian and Variscan metamorphic events in the Léon domain (Armorican Massif, France): P-T data and EMP monazite dating, in: U. Linnemann, R.D. Nance, P. Kraft, G. Zulauf (Eds.), The evolution of the Rheic Ocean: From Avalonian-Cadomian active margin to Alleghenian-Variscan collision, Geol. Soc. Am. Spec. Paper 423 (2007) 267-285.

[86] R.C. Scrivener, Cornubian granites and mineralization of SW England, in: P.J. Brenchley, P.F. Rawson (Eds.), The Geology of England and Wales, Geol. Soc. Lond. (2006) 257-267.

[87] E.B. Selwood, A review of basin development in Central SW England, Proc. Ussher Soc. 7 (1990) 199-205.

[88] R.K. Shail, J.J. Wilkinson, Late- to post-Variscan extensional tectonics in south Cornwall, Proc. Ussher Soc. 8 (1994) 228-36.

[89] R.K. Shail, A.C. Alexander, Late Carboniferous to Triassic reactivation of Variscan basement in the western English Channel: evidence from onshore exposures in south Cornwall, J. Geol. Soc. Lond. 154 (1997) 163-168.

[90] R.K. Shail, F.M. Stuart, J.J. Wilkinson, A.J. Boyce, The role of post-Variscan extensional tectonics and mantle melting in the generation of the Lower Permian granites and 
the giant W-As-Sn-Cu-Zn-Pb orefield of SW England, Applied Earth Science (Trans. Inst. Min. Metall., Sect. B) 112 (2003) 127-129.

[91] S.C. Sherlock, K.A. Jones, J.A. Jones, A central European Variscide source for Upper Carboniferous sediments in SW England: ${ }^{40} \mathrm{Ar} /{ }^{39} \mathrm{Ar}$ detrital white mica ages from the Forest of Dean Basin, J. Geol. Soc. Lond. 157 (2000) 905-908.

[92] G.M. Stampfli, J.F. von Raumer, G.D. Borel, Palaeozoic evolution of pre-Variscan terranes: From Gondwana to the Variscan collision, in J.R. Martínez Catalán, R.D. Hatcher, R. Arenas, F. Díaz García (Eds.), Variscan-Appalachian dynamics: The building of the late Palaeozoic basement, Geol. Soc. Am. Spec. Paper 364 (2002) 263-280.

[93] J.A. Stimac, A.H. Clark, Y. Chen, S. Garcia, Enclaves and their bearing on the origin of the Cornubian batholith, southwest England, Min. Mag. 59 (1995) 273-296.

[94] J. Tait, New Early Devonian paleomagnetic data from NW France: Paleogeography and implications for the Armorican microplate hypothesis, J. Gephys. Res. B104 (1999) 28312839.

[95] G.K. Taylor, Pluton shapes in the Cornubian Batholith: new perspectives from gravity modelling, J. Geol. Soc. Lond. 164 (2007) 525-528.

[96] L.N. Warr, T.J. Primmer, D. Robinson, Variscan very low-grade metamorphism in southwest England: a diastathermal and thrust-related origin, J. Metamorph. Geol. 9 (1991) 751-64.

[97] N.H. Woodcock, N.J. Soper, R.A. Strachan, A Rheic cause for the Acadian deformation in Europe, J. Geol. Soc. Lond. 164 (2007) 1023-1036. 


\section{Figure captions}

Fig. 1. Simplified geological map of SW England, modified after [58]. Inset shows location within European Variscides.

Fig. 2. Simplified geological map of the Lizard Complex, after [19,37,72].

Fig. 3. Progressive development of SW England passive margin basins during Devonian, after $[60]$.

Fig. 4. Simplified geological map of Gramscatho Basin, showing principal structural units, after [59].

Fig. 5. Schematic N-S cross-sections, showing progressive inversion of the SW England passive margin. A: Early stages (Visean). B: Detail of Culm Basin (Westphalian). C: Cartoon depicting rift basin geometry control on inversion style. D: End-Westphalian (convergence ceased). After $[58,60]$.

Fig. 6. Simplified tectonic map of southern Britain and NW France showing the key elements that are discussed in the text and form the basis for models in Fig. 7; modified after $[30,45,31,71]$.

Fig. 7. Cartoon showing some of possible relations between the development of the SW England Rhenohercynian passive margin and the Rheic Ocean; in part after [31,38,92]. 
Figure 1 - revised (full page width)

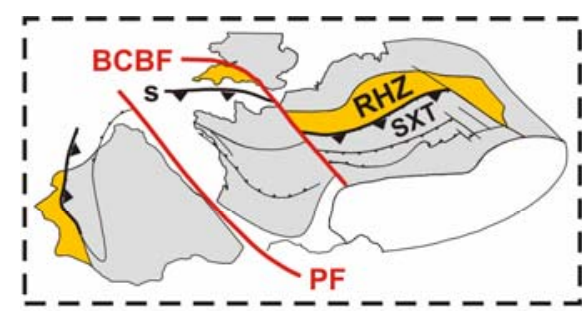

SW England located in Rhenohercynian Zone (RHZ) to north of suture (s) with Saxothuringian Zone (SXT); bound by Bristol Channel-Bray Fault (BCBF) and Pyrenean Fault (PF)

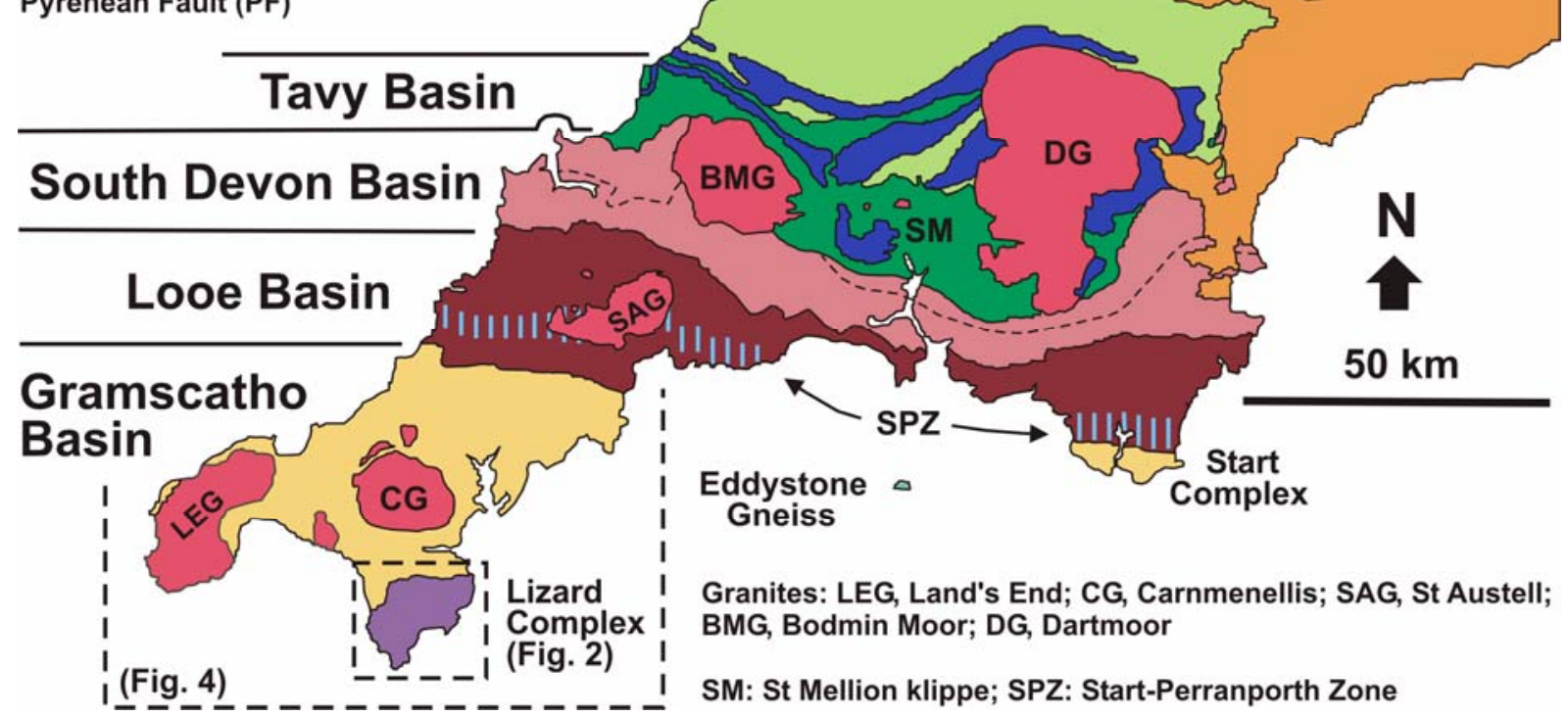

Figure 2 - revised (single column width)

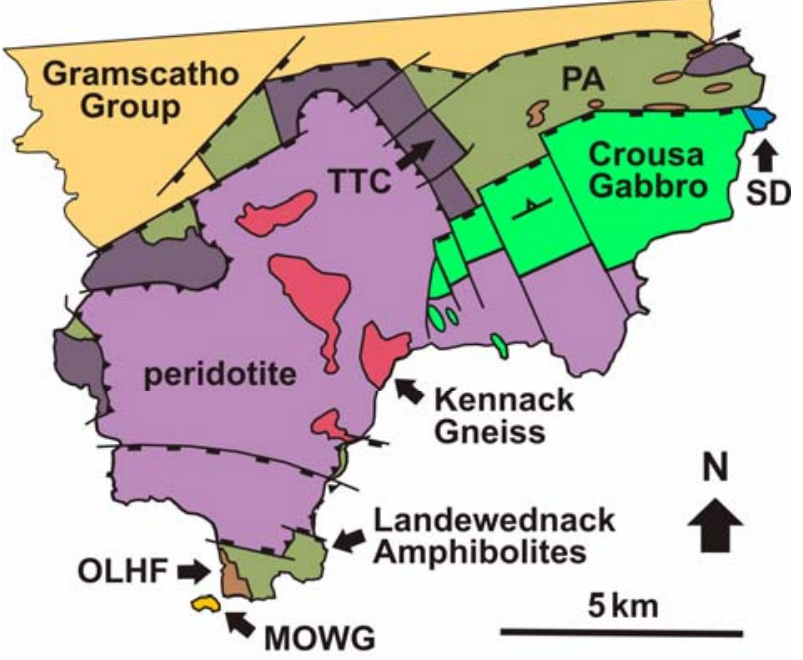

MOWG: Man of War Gneiss; PA: Porthoustock Amphibolites

OLHF: Old Lizard Head Formation; SD: sheeted dykes

TTC: Traboe Cumulate Complex 
Figure 3 - revised (single column width)

a EMSIAN

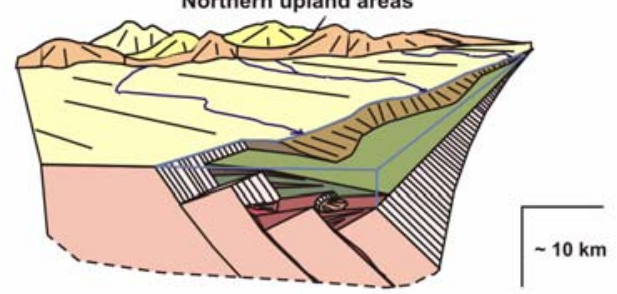

LOOE BASIN

b GIVETIAN Northern upland areas

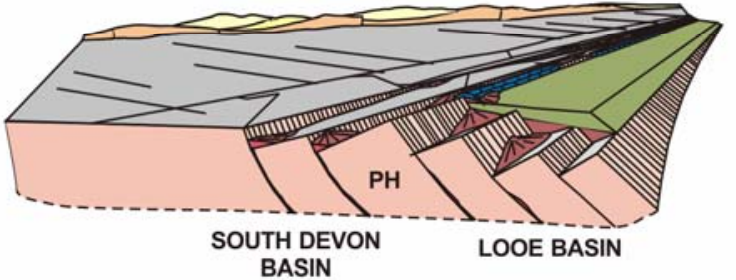

c FRASNIAN

Northern upland areas

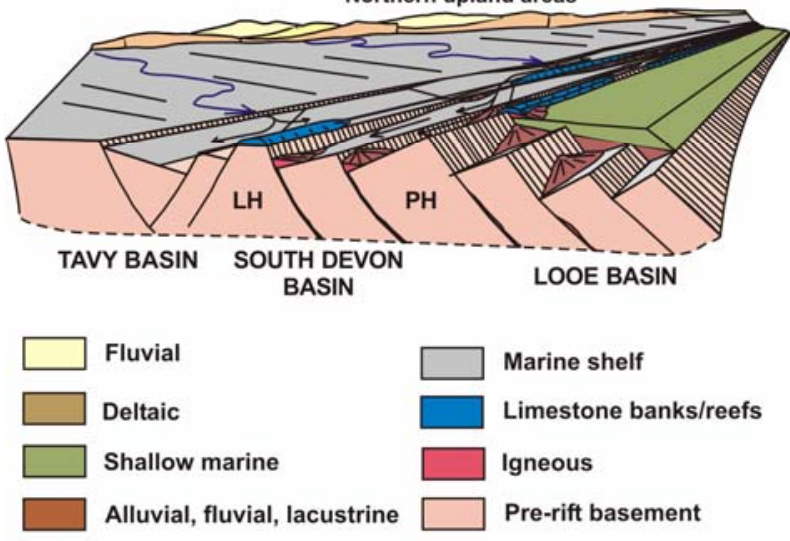

LH: Landulph High $\quad$ PH: Plymouth High

Figure 4 (single column width)

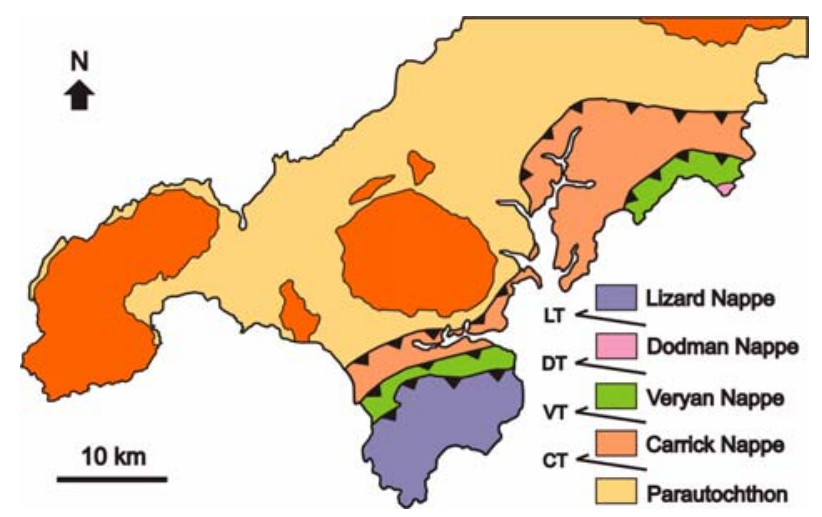


Figure 5 - revised (full page width)

a VISEAN

N

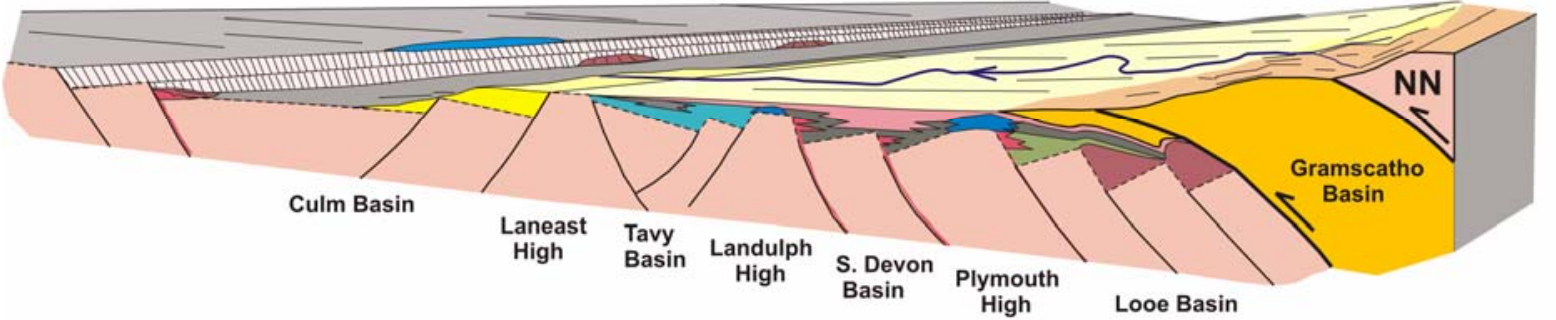

b WESTPHALIAN

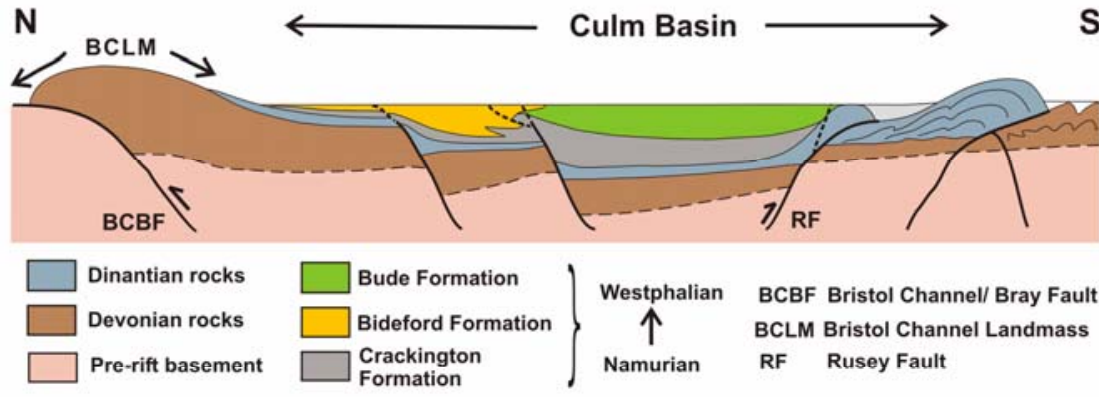

d LATEST WESTPHALIAN

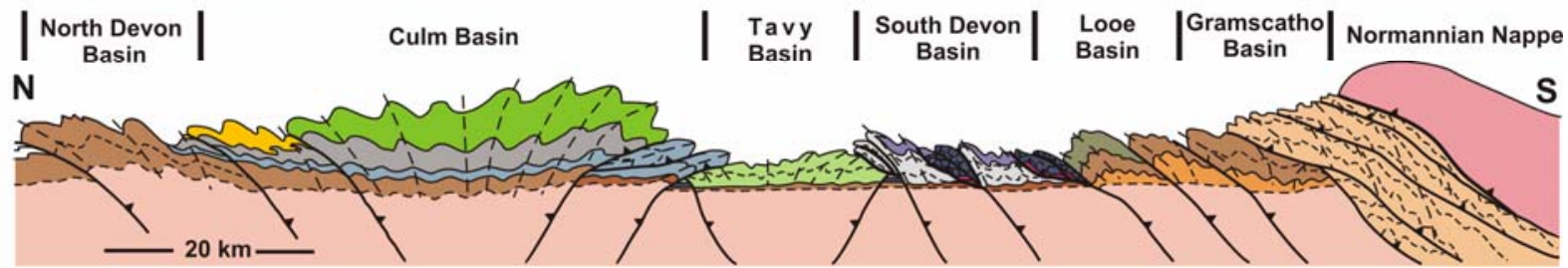

c INVERSION STYLE
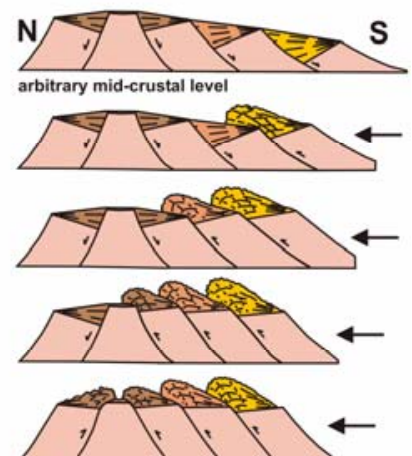

Figure 6 - new figure (single column width)

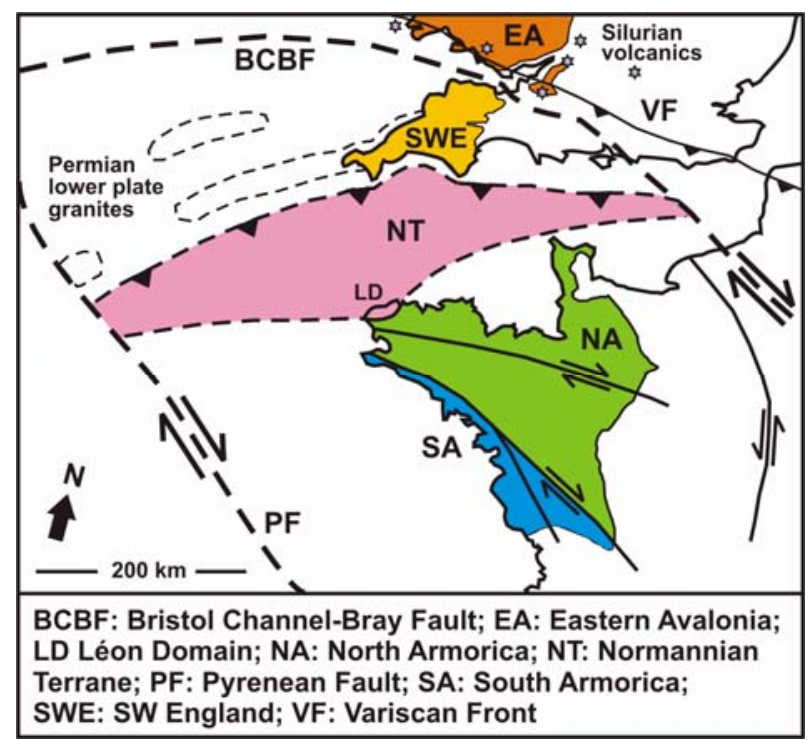


Figure 7 - new figure (single column width)

\section{A: $\mathbf{R H Z}$ is $\mathbf{N}$ margin of Rheic Ocean}

NW

Early Devonian

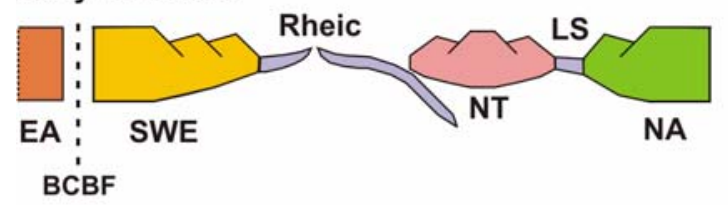

B: RHZ is successor basin to Rheic Ocean

Early Silurian

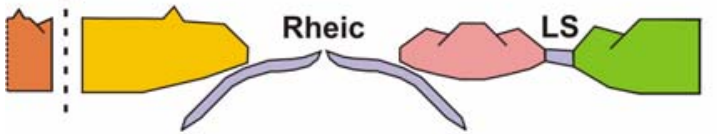

Late Silurian

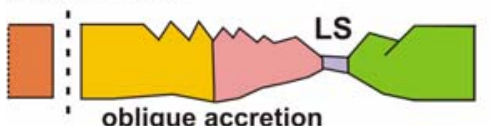

Early Devonian

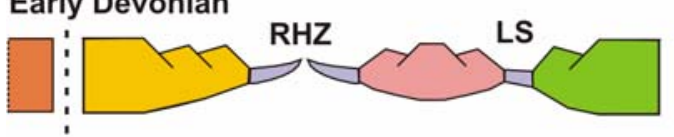

\section{C: RHZ is marginal basin to Rheic Ocean}

(1) Rifting after accretion of NT to EA

Early Silurian

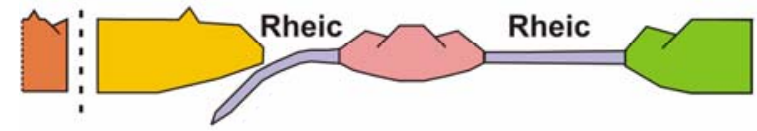

Late Silurian

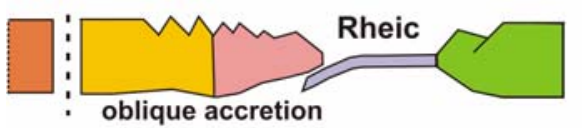

Early Devonian

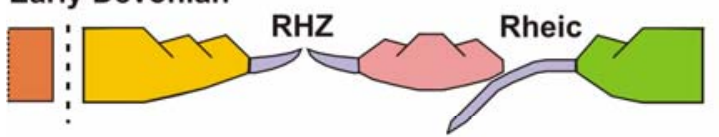

(2) Rifting of EA after Rheic ridge subduction Early Devonian

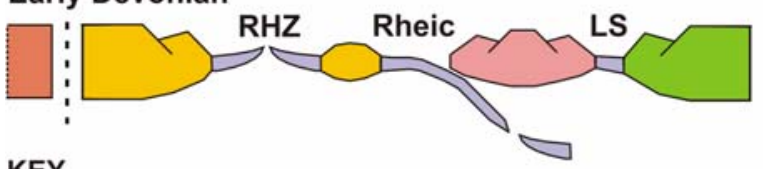

KEY

EA: Eastern Avalonia; BCBF: Bristol Channel-Bray Fault SWE: SW England; NT: Normannian Terrane; LS Léon Sea NA: North Armorica 